\title{
ESTUDO SEMIÓTICO DO SLOGAN DA CAMPANHA BOLSONARISTA: BRASIL ACIMA DE TUDO, DEUS ACIMA DE TODOS
}

\author{
Dulce Helena Pontes-Ribeiro ${ }^{1}$
}

RESUMO: Este estudo apresenta uma das possibilidades de análise semiótica do slogan Brasil acima de tudo, Deus acima de todos, utilizado pelo candidato Jair Messias Bolsonaro na campanha eleitoral de 2018 à Presidência da República do Brasil. O objetivo foi analisar como esse bordão pode ter contribuído como elemento catalisador da decisão para eleger o candidato, centrando-se na força semiótica desse bordão interligado a outros artifícios para que fosse absorvido pelo eleitor brasileiro. Metodologicamente, após uma revisão bibliográfica sobre imagem (Roland Barthes, 1964), retórica política e prática discursiva da particitação (Dominique Maingueneau, 2005), slogan (Luiz Carlos Assis Iasbeck, 2002), e semiótica discursiva (Algirdas Julien Greimas, 1975) - pilares deste estudo -, procede-se ao estudo de caso. Como resultados, discorre-se sobre o contexto propício dessa palavra empenhada confundindo-se com a identidade como a desejada para dar um basta ao caos político do País. Apresentam-se elementos transcendentes ao visual e ao textual ao evocar valores, sensações e narrativas que vão ao encontro das expectativas do eleitorado.

Palavras-chave: semiótica discursiva. Slogan. retórica política. imagem.

ABSTRACT: This study presents one of the possibilities for a semiotic analysis of the slogan "Brazil above all, God above all", used by candidate Jair Messias Bolsonaro in the 2018 election campaign for the Presidency of the Republic of Brazil. The purpose was to analyze how this staff may have contributed as a catalyst to the decision to elect the candidate, focusing on the semiotic force of this interlocked bond to other devices to be absorbed by the Brazilian voter. Methodologically, after a bibliographical revision on image (Roland Barthes, 1964), political rhetoric and discursive practice of participation (Dominique Maingueneau, 2005), slogan (Luiz Carlos Assis Iasbeck, 2002) and discursive semiotics (Algirdas Julien Greimas, 1975) pillars of this study - we proceed to the case study. As results, we discuss the propitious context of this committed word, confusing itself with identity as the one desired to put an end to the political chaos of the Country. Transcendent elements are presented to the visual and to the textual by evoking values, sensations and narratives that meet the expectations of the electorate.

\footnotetext{
' Doutora em Letras - Área de concentração: Língua Portuguesa pela Universidade do Estado do Rio de Janeiro (Uerj). Mestre em Educação pela Universidade Católica de Petrópolis (UCP). Pós-graduada lato sensu em Língua Portuguesa e Graduada em Letras pela Faculdade de Filosofia de Itaperuna (Fafita) e em Semiótica Discursiva pela Universidade de |Araraquara (Uniara). Professora aposentada da rede estadual de ensino, RJ. Professora no Centro Universitário São José (Unifsj) de Português: origem e evolução, Latim: língua e cultura e Metodologia de TCC. Revisora da revista acadêmica Transformar. Revisora de textos científicos, acadêmicos, TCC, livros, etc.
} 
Keywords: discursive semiotics. Slogan. political rhetoric. image.

\section{INTRODUÇÃO}

Por 13 anos e 13 dias de governo petista - eleição e reeleição diretas de Luís Inácio Lula da Silva (Lula), por 8 anos, e Dilma Rousseff, o restante -, o Brasil viveu anos de ascensão econômica e paralelamente fenomenais escândalos políticos de corrupção do alto escalão governamental, resultando, inclusive, no impeachment da presidente após se tornar ré por crime de responsabilidade fiscal. Michel Temer, presidente interino no processo de impeachment, assume definitivamente, em 2016, a presidência do País, sob protestos de insatisfação, mediante uma reprovação popular inédita.

Nesse marasmo, que em muito atingiu a economia, a segurança e também a ética pública, emerge a figura do capitão reformado, de 63 anos, Jair Messias Bolsonaro, candidato de direita à presidência da República, católico, empenhado em resgatar valores conservadores. Para tanto, aproveitou-se de um slogan da Brigada Paraquedista do Exército (Brasil acima de tudo) como mote de sua campanha. Segundo Maingueneau (2005), diferente de um slogan, trata-se de particitação (palavra-valise que aglutina participação e citação). Distingue-se da citação, quando, muitas vezes, se utiliza o verbo dicendi para anunciar a fala do outro. Já na particitação, o enunciado citado é

[...] um enunciado autônomo, porque ele já o é originalmente ou porque ele foi previamente autonomizado mediante sua extração de um texto. [...]

[...] apresentado em seu significante, dentro de uma lógica de discurso direto, mas levada ao extremo: não se trata apenas de simular - como geralmente ocorre no discurso direto -, mas de restituir o próprio significante. [...] A restituição do significante é evidentemente associada ao fato de que não há indicação da fonte da fala citada.

O locutor que cita mostra sua adesão ao enunciado citado, que pertence àquilo que se poderia denominar um Thesaurus de enunciados de contornos mais ou menos fluidos, indissociável de uma comunidade onde circulam esses enunciados e que, precisamente, se define de maneira privilegiada por compartilhar um tal Thesaurus. Por sua enunciação, o locutor que cita 
pressupõe pragmaticamente que ele mesmo e seu alocutário são membros dessa comunidade, que eles são arrebatados em uma relação de tipo especular: o locutor cita aquilo que poderia/deveria ser dito pelo alocutário e, mais amplamente, por todo membro da comunidade que age de maneira plenamente conforme a esse pertencimento.

Esse Thesaurus e a comunidade correspondente recorrem a um hiperenunciador cuja autoridade garante menos a verdade do enunciado - no sentido estreito de uma adequação a um estado de coisas do mundo -, e mais amplamente sua "validade", sua adequação aos valores, aos fundamentos de uma coletividade (MAINGUENEAU, 2005, p. 77-78).

Assim então foi utilizado o slogan por Bolsonaro. Slogan é "Um sintagma verbal bem arquitetado e acusticamente agradável, pode ser facilmente memorizado e incansavelmente repetido" (IASBECK, 2002, p. 58). É claro que o candidato se utilizou de outros expedientes muito eficazes e que foram negligenciados (ou ineficientemente utilizados) por seus adversários: as redes sociais (Facebook, Twitter e WhatsApp) - o que

$\mathrm{fez}$ com que os eleitores bolsonaristas se tornassem propagandistas e plataformas de encaminhamento de mensagens de Bolsonaro.

Mas o que interessa a este estudo é buscar respostas a este questionamento: até que ponto a força semiótica de um slogan acoplado numa campanha presidencial consegue se infiltrar no pensamento da população brasileira contribuindo sobremaneira como elemento catalisador da decisão para eleger o presidente do País? Esta é a questão-problema emersa da situação vivenciada no contexto brasileiro de 2018, que, sob o viés da análise semiótica discursiva, encaminha a discussão acerca do slogan político utilizado em campanha eleitoral. Faz-se aí uma reflexão sobre o poder e a legitimidade da palavra empenhada por seu interlocutor, configurando sua identidade como a desejada pela grande massa do eleitor brasileiro para governar o país.

A justificativa deste trabalho está no fato de se trazer à discussão um aspecto que vai muito além da política, pois envolve a vida do homem em todas as esferas, cercada de palavras por todos os lados, muitas das quais dirigem as suas atitudes ainda que ele não o perceba, em razão da opacidade delas nos slogans. Por estes, as palavras são projetadas e 
atingem mais que os ouvidos do receptor, atingem coisas que ainda não são, as não coisas, um devir. Essas palavras são arremessadas para longe, para um futuro delineado pelo seu anunciante, porém não permitem que o receptor detecte a força persuasiva delas, a capacidade de arrebanhar campos cada vez mais amplos.

Portanto, a pesquisa é relevante tanto para o usuário da língua que se preocupa em não ser manipulado por palavras e imagens quanto para estudiosos das letras que desejam se embrenhar pelas veredas da semiótica discursiva e verificar a aproximação e infiltração dela no cotidiano da contemporaneidade.

\section{OBJETIVOS}

Tendo em vista responder à questão-problema lançada mais acima na introdução (até que ponto a força semiótica de um slogan acoplado numa campanha presidencial consegue se infiltrar no pensamento da população brasileira contribuindo sobremaneira como elemento catalisador da decisão para eleger o presidente do País?), procurou-se traçar os objetivos deste trabalho.

\section{I Objetivo Geral}

Demonstrar, sob à luz da semiótica discursiva, como o slogan Brasil acima de tudo, Deus acima de todos pode apresentar elementos que transcendem o visual e o textual, evocando valores, sensações, narrativas que vão ao encontro das expectativas do eleitorado.

\subsection{Objetivos Específicos}

I) discorrer sobre semiótica discursiva sobrelevando a confluência entre imagem e texto;

2) caracterizar slogan, abordando seu surgimento, sua trajetória histórica e seu poder de influência;

3) traçar sumariamente o contexto político brasileiro contemporâneo; 
4) analisar alguns exemplos da retórica política do candidato Bolsonaro que mantiveram confluência com o slogan de sua campanha, associando-o a imagens utilizadas por ele: bandeira nacional e uso de camisa amarela nos comícios, ou seja, analisar o Percurso Gerativo do Sentido desse slogan.

\section{METOdOLOGiA}

Acerca da metodologia, explica-se que, num primeiro momento, como é de praxe em trabalhos acadêmico-científicos, realizou-se uma revisão de literatura para que, embasado teoricamente, a pesquisadora pudesse analisar com critérios bem definidos seu objeto de estudo.

Nessa parte, conforme Antônio Carlos Gil (2002), houve várias etapas. Após escolha do tema e formulação do problema, fez-se um levantamento bibliográfico preliminar, ainda numa fase exploratória em que das fontes de leitura resultaram fichamentos e redações embasadas nos teóricos. Em seguida, partiu-se para a análise semiótica do objeto de estudo - o slogan Brasil acima de tudo, Deus acima de todos paralelamente, a dados do enunciador (Bolsonaro), da cultura do povo brasileiro e da situação do país deflagradores da escolha do texto verbal e das imagens que o acompanham. São dados que ajudaram na compreensão da opacidade das palavras e do que havia por trás da aparente neutralidade das imagens (bandeira do Brasil, camisa amarela). Em outras palavras: fez-se o PGS.

Assim, a utilização da semiótica como método de análise demandou, como todo e qualquer método, procedimentos imprescindíveis: planejamento e definição de roteiro da investigação, tais como os delineados aqui; escolha das imagens a serem analisadas; coleta de dados do anunciante e do público ao qual é dirigida a mensagem (hábitos, costumes e comportamentos) - para, enfim, detectar a intenção motivadora.

Por essas características que trouxeram à tona minúcias e profundidades, e certo fenômeno de uma situação bem delimitada - embora as descobertas relevantes não possam generalizar amplamente a questão -, esta pesquisa pode ser classificada como um estudo de caso (EC). Consoante Robert Yin (2015), o EC tem as seguintes características:

I) “focaliza acontecimentos contemporâneos"; 
2) "não exige controle sobre eventos comportamentais";

3) o pesquisador trabalha "com afinco para expor todas as evidências de forma justa”;

4) “o objetivo é fazer uma análise 'generalizante' e não 'particularizante”;

5) "pode evitar totalmente as maçantes narrativas tradicionais";

6) os EC "são uma forma de inquirição que não depende exclusivamente dos dados etnográficos ou de observadores participante";

7) um EC "é uma investigação empírica que: - investiga um fenômeno contemporâneo dentro de seu contexto da vida real, especialmente quando - os limites entre o fenômeno e o contexto não estão claramente definidos" (YIN, 2015, p. 21; 29; 30).

Pelo teor da pesquisa, "a natureza dos dados coletados, a extensão da amostra, os instrumentos de pesquisa e os pressupostos teóricos que nortearam a investigação", ela se caracteriza como qualitativa (GIL, 2002, p. 133). É um tipo de pesquisa que pode conduzir o pesquisador à subjetividade. Para evitar esse risco, seguiu-se os conselhos de Gil (2002, p. I5I): a utilização concomitante de técnicas estruturadas e a adoção de "quadros teóricos de análise que emprestam maior significação e generalidade aos dados obtidos”.

Para a análise semiótica, a perspectiva adotada foi a de Algirdas Julien Greimas (1975), tanto no plano da expressão quanto no plano não verbal em que há uma hierarquia de sensações; preocupa-se com os mecanismos que geram o discurso; objetiva elaborar uma teoria da significação para explicar as linguagens. A noção de significação se rege por uma tríade semiótica (significante, significado, objeto real) que explica os processos perceptivos, cognitivos e pragmáticos relacionados ao uso de signos; descreve e explica o que o texto diz e a manobra utilizada para tanto, o percurso percorrido nesse empenho, partindo do mais simples e abstrato para o mais complexo e concreto. Assim, a superfície do texto está abastecida de elementos concretos provenientes das relações semânticas simples e abstratas instauradas no percurso.

Para as discussões de análise discursiva, houve outros pilares do embasamento teórico como Roland Barthes (1964), Dominique Maingueneau (2005), José Luiz Fiorin 
(1999, 2000, 2002) por exemplo, e demais autores que tratam especificamente do slogan, como é o caso de Luiz Carlos Assis Iasbeck (2002).

As imagens que utilizam o slogan foram retiradas do site oficial de Bolsonaro, que é o<https://www.bolsonaro.com.br/>.

\section{RESULTADOS E DISCUSSÃO}

Esta seção se estrutura em quatro subseções. A primeira (Semiótica Discursiva) começa explicando o que é semiótica, como surgiu e focaliza depois a semiótica discursiva, abordando a relação imagem e texto no discurso. A segunda, (Slogan) conceitua slogan, seu surgimento, trajetória histórica e poder de influência sobre o público receptor. A terceira, (Brasil acima de tudo, Deus acima de todos: um estudo de caso) apresenta informações significativas do momento político de 2018 contemporâneo às eleições presidenciais, para, em seguida, trazer à pauta o candidato Jair Messias Bolsonaro bem como sua retórica política acompanhada do uso de imagens patriotas. Por fim, vem a subseção da análise semiótica greimasiana do slogan utilizado pelo referido candidato, que é o corpus de análise deste estudo.

\section{I Semiótica Discursiva: imagem e texto}

A semiótica greimasiana é uma disciplina coesa e complexa, com potencial de perscrutar, em textos verbais, não verbais e sincréticos, a produção do sentido; ancora-se, essencialmente, nos pressupostos teóricos saussureanos e hjelmslevianos, mas o seu autor fundador, Algirdas Julien Greimas, recorreu a outras fontes também como a fenomenologia e a antropologia.

Saussure (2006, p. 24) deu o nome de "Semiologia" à disciplina que se ocupa da "vida dos signos no seio da vida social”, de todos os signos, uma ciência geral da qual faz parte a linguística (sistemas de signos linguísticos). Criou os termos significante, significado e signo linguístico (significante + significado). Para ele, a substância precede a forma; o pensamento é anterior à língua: "[...] tomado em si, o pensamento é como uma nebulosa onde nada está necessariamente delimitado" (SAUSSURE, 2006, p. 130). 
Diferente de Saussure, para Hjelmslev, a substância não precede a forma, mas depende exclusivamente da forma e não existe sem ela $\mathrm{O}$ que aquele chama de significante, para este é plano de expressão. O que aquele chama de significado, para este é plano de conteúdo - ainda que estes termos não se constituam em sinônimos precisos. A substância do conteúdo resulta da forma do conteúdo, portanto a língua cria o mundo, e este dá sentido àquela já que é estruturado via linguagem. $\mathrm{O}$ autor denomina de função semiótica a relação que une duas grandezas (conteúdo e expressão), pois "uma expressão só é expressão porque é expressão de um conteúdo, e um conteúdo só é conteúdo porque é conteúdo de uma expressão" (HJELMSLEV, 2006, p. 54).

Greimas se vale da dicotomia saussureana para a percepção das diferenças, já que um termo/objeto sem o seu oposto nada significa. Ao notar que todo texto tem sua própria estrutura e que não é o mesmo que a soma de suas partes, Greimas processa a guinada da semântica para a semiótica, que é, segundo o autor, "a linguagem que autoriza falar do sentido" (GREIMAS, I975, p. 17). Este, então, é o objeto da semiótica: o sentido (o parecer do sentido) perceptível pela expressão e conteúdo - resultado da função semiótica. A propósito, "vivemos num mundo significante e o sentido se coloca como um 'sentimento de compreensão' absolutamente natural" (GREIMAS, I975, p. I2).

Greimas (1976) se serve de dois pares da teoria de Hjelmslev: expressão/conteúdo (para introduzir a função semiótica e objetivar sua teoria) e forma/substância (para aferir e ajuizar o que encontrou). Sua teoria não incide sobre o signo constituído, mas nas partes constituintes deste; ela se abre para o processo, para o discurso, para estudos num sentido amplo, colocando de um lado a expressão e de outro o conteúdo; um conteúdo pode ser veiculado por qualquer expressão (verbal, tátil...).

Assim, embasando o estudo do texto e do discurso nos postulados de Saussure e Hjelmslev, Greimas (1976, p. II) cria, no pilar das ciências humanas, a semiótica discursiva, que é uma teoria da significação, pois “[...] o mundo humano se define essencialmente como o mundo da significação. Só pode ser chamado 'humano' na medida em que significa alguma coisa”. A percepção do sentido, para Greimas (1976, p. 15), é “o lugar não linguístico onde se situa a apreensão da significação”; portanto, esta ocorre no domínio da 
percepção. Assim, a preocupação da semiótica é com o sentido do parecer, e não com o ontológico; e tudo que produz sentido é texto: fotografia, canção, jogo de pôquer, etc.

Princípios estruturais e concepção de língua como instituição social são indícios saussuriano e hjelmsleviano distintos na semiótica greimasiana. Porém há marcas também da antropologia cultural (no conhecimento do que gere e atravessa o discurso, a influência cultural na formação do imaginário humano, nos passos de Lévi-Strauss e Marcel Mauss) e da filosofia fenomenológica de Merleau-Ponty, atenta com o parecer de certo objeto empírico/ontológico. Assim, o parecer na semiótica se constrói no e pelo discurso, sem se deter à correlação entre um referente da realidade. Greimas (1976) criou uma teoria semiótica com estas características: sintagmática (preocupada com expressão e conteúdo), geral (para qualquer tipo de texto e qualquer materialidade/suporte) e gerativa (sentido gerado no percurso de produção, passível de ser fatiado em camadas, partindo do mais simples/abstrato ao mais complexo/concreto).

Pelo fato de a semiótica greimasiana priorizar o texto e seus mecanismos intradiscursivos para a constituição do sentido, ela vem sendo muito criticada, mas ela não negligencia os contextos histórico e social, e os toma como textos, na medida em que possam dialogar com o texto em análise. Essa direção, estruturalista, tem base saussureana e hjelmsleviana, no princípio da imanência e adentra os domínios da enunciação, paixões, expressão e continuidade (LARA; MATTE, 2009, p. 70).

A teoria de Greimas, influenciada na fenomenologia, se desdobra para o ponto de vista tensivo da semiótica (sem, contudo, abrir mão das bases linguísticas) e, no discurso, associa-se ao nível sensível da percepção e dos afetos, às nuances, complexidades e imbricações. E assim introduz um continuum à teoria que se configura como potencialidade de sentido. O sentido na semiótica tensiva (diferente do quadrado semiótico apresentado em mais adiante na Figura I), passa de estático, estruturado, a dinâmico, instável, da ordem do devir. Desapegada do estruturalismo engessado, a semiótica tensiva se constitui como “entidade autônoma de dependências internas” (HJELMSLEV, I991, p. 29).

Assim, a semiótica greimasiana fundada pelos princípios do estruturalismo, dualismo e arbitrariedade da semiologia saussureana (primeira fase), perpassando pelo princípio da imanência de base teórica da linguagem de Hjelmslev (segunda fase), chega à 
teoria semiótica sensível subordinada ao princípio da imanência (afeto, sensibilidade), expandindo o texto para o contexto, interdiscurso e mesmo situações intersubjetivas da vida humana. Portanto, as análises sob a perspectiva da semiótica discursiva greimasiana transcendem a sua narrativa, como se vê na sequência deste estudo.

A análise semiótica passa a descrever e explicar dispositivos que instituem o sentido do texto, transcendendo, portanto, o âmbito da palavra/frase (semântica), apreendendo a construção do sentido do texto como uma totalidade. Sublinha-se que toda língua natural possibilita diversos planos de leitura por isso nunca é absolutamente denotativa; portanto, conforme Greimas (1975), o normal é o homem viver sob a ameaça permanente da metáfora. Neste mundo do parecer significar, o questionamento dos sentidos é um encargo metalinguístico laborioso e a descrição semiótica da significação nada mais é que a elaboração de uma linguagem plástica, postiça, ajustada para demonstrar a estruturação do sentido, "porque a forma semiótica é exatamente o sentido do sentido" (GREIMAS, I975, p. 17)", é a produção de dado sentido, é um curso, uma direção, pois não se restringe ao que dizem as palavras/frases. Por conseguinte, "o sentido enquanto forma do sentido, pode ser definido então como a possibilidade de transformação do sentido" (GREIMAS, i975, p. i5).

Greimas apresenta o percurso gerativo do sentido como o caminho que explica as formas e estratégias de produção do sentido do discurso persuasivo, o qual passa por três níveis de sintaxe e semântica próprias: fundamental, narrativo e discursivo.

No nível fundamental, há as categorias semânticas que estão na base da construção do texto. A significação se apresenta pelo dualismo opositor (p.ex.: amor vs ódio), cujos termos, pela operação de sintaxe elementar, são afirmados (euforia - qualificação semântica de valor positivo) ou negados (disforia - qualificação semântica de valor negativo). Mas o fato de certo termo ser eufórico ou disfórico depende do discurso. Por exemplo: $\mathrm{O}$ amor vence barreiras (termo eufórico) vs $\mathrm{O}$ amor mata (termo disfórico). Portanto, os fatores euforia/disforia não estão nas palavras, e sim no contexto do discurso. Disforia e euforia são construídas no e pelo texto, e não previamente, de modo que aquilo que é considerado amor num texto pode não o ser em outro. E mais: antes de um estado A 
se converter a um estado $\mathrm{B}$, ele passa pela negação de si próprio (NÃO-A). Esses podem ser assim entendidos:

Quadro I - Euforia/disforia

\begin{tabular}{|l|l|}
\hline Foria: força propulsora & Estado de \\
\hline Euforia & Relaxamento \\
\hline Disforia & Tensão \\
\hline Não euforia & Retensão \\
\hline Não disforia & Distensão \\
\hline
\end{tabular}

Fonte: Elaboração própria

Essa sintaxe fundamental/elementar se ocupa das relações de:

I) contrariedade - em todo discurso há relações contrárias. Por exemplo: quando se diz que alguém é rico também está se dizendo, mesmo sem palavras, que esse alguém não é pobre. Portanto, na semântica, o que se diz com palavras é tão importante quanto o que se diz sem elas;

2) contraditoriedade - são as relações estabelecidas entre palavras contraditórias. Por exemplo: nas relações entre herói vs vilão não significa que toda pessoa que não é herói seja vilão; havendo, portanto, o herói e o não herói. Isto é contraditoriedade, e não contrariedade. A contrariedade seria herói vs vilão;

3) complementariedade/implicação - são palavras de cargas semânticas próximas. Por exemplo: um vilão e um não herói, um feio e um não bonito, um não feio e um bonito. O quadrado semiótico (Figura 2) abaixo resume esse modelo lógico de relações.

Assim, a semiótica greimasiana fundada pelos princípios do estruturalismo, dualismo e arbitrariedade da semiologia saussureana (primeira fase), perpassando pelo princípio da imanência de base teórica da linguagem de Hjelmslev (segunda fase), chega à teoria semiótica sensível subordinada ao princípio da imanência (afeto, sensibilidade), expandindo o texto para o contexto, interdiscurso e mesmo situações intersubjetivas da 
vida humana. Portanto, as análises sob a perspectiva da semiótica discursiva greimasiana transcendem a sua narrativa, como se vê na sequência abaixo.

Figura I - Quadrado semiótico

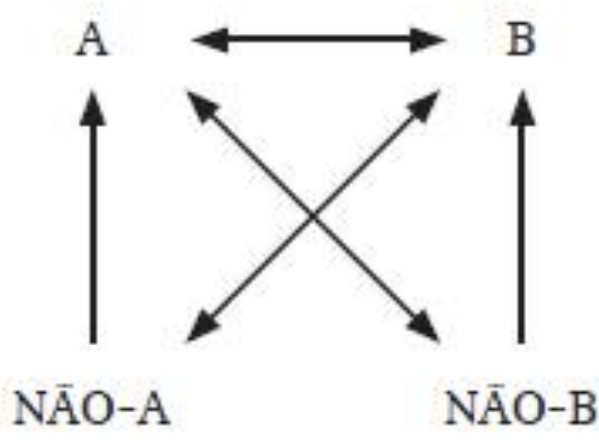

Fonte: Semiosis. Disponível em: 〈https://bit.ly/2DWkmG7>. Acesso em: 02 dez. 2018.

A, B, NÃO-A e NÃO-B são termos hipotéticos e representam categorias semânticas fundamentais em oposição como, por exemplo, amor (A) e ódio (B). Os termos A e B - assim como NÃO-A e NÃO-B - são opostos (relação de contrariedade). Entre os termos A e NÃO-A e $\mathrm{B}$ e NÃO-B se dá uma relação de contradição/contraditoriedade. E entre NÃO-A e B e NÃO-B e A ocorre uma relação de implicação/complementaridade. Tais relações nesse quadrado semiótico compõem a sintaxe, que apresenta duas operações: a asserção e a negação; já seus conteúdos são da ordem da semântica do nível fundamental.

$\mathrm{Na}$ sintaxe narrativa há dois tipos de enunciado: $\mathrm{I}$ ) de estado; 2 ) de fazer (onde há transformação). Para Greimas, a narratividade ocorre pela mudança de estado do sujeito em relação ao objeto, realizada explícita ou implicitamente. Há na sintaxe narrativa uma sequência/esquema canônico, composto de quatro fases:

I) manipulação - transmissão de um querer/dever fazer de um sujeito a outro, por tentação, sedução, provocação ou intimidação; 
2) competência - atribuição de condição de um sujeito a outro, ou a si próprio, de um saber/poder fazer;

3) performance - fase da mudança, transformação principal da narrativa;

4) sanção - reconhecimento de modo pragmático (com punição ou castigo); ou cognitivo (sem prêmio e sem castigo) da ocorrência da performance. Mas, "a sequência canônica não é uma fôrma onde se faz caber a narrativa", diz Fiorin (1999).

Por fim, vem o nível discursivo, o de estruturas mais concretas e complexas. $\mathrm{O}$ texto se compõe de isotopia (recorrência de traços), facultando mais planos de leitura para um mesmo texto. A sintaxe discursiva é organizada a partir das projeções da enunciação no enunciado (temporalização, espacialização e actorialização) para persuadir e manipular o enunciatário.

Todos esses mecanismos produzem efeitos de sentido no discurso. Não é indiferente um narrador projetar-se no enunciado ou alhear-se dele; simular uma concomitância dos fatos narrados com o momento de enunciação ou apresentá-los como anteriores ou posteriores a ele; presentificar o pretérito; enunciar um eu sob a forma de um ele, etc. (FIORIN, 2002, p. 54).

Cada análise desconstrói o texto para perceber o engendramento dos sentidos nele presentes; portanto cada análise é uma análise distinta, e não uma camisa de força onde cabem todos os componentes do texto. Pode-se, portanto, analisar um texto pela produção do sentido considerando seus mecanismos sintáticos e semânticos ou pela relação dialógica com outros textos, considerando-o como um objeto cultural, imerso, portanto, em determinadas condicionantes históricas. O nível mais concreto de concepção do sentido é considerar o objeto sob várias perspectivas.

Quando o sujeito cognoscente analisa certo objeto apenas sob uma perspectiva, atribui certeza a esse conhecimento e nega outras concepções, tendo-as como equivocadas. A análise de um texto parte de um todo (complexo) para a(s) parte(s) (simples). Na sua produção, o caminho é inverso: parte-se da parte para o todo, havendo no processo um nível de abstração intermediária. Assim, o processo gerativo de sentido, ao partir do simples ao complexo, passa por uma sucessão de patamares que vai do nível profundo 
(fundamento) ao narrativo (da superfície) e ao discursivo (da expressão). "Cada combinatória de formas produz um determinado sentido" (FIORIN, 2000, p. I8).

Apreender figuras isoladas em um texto não é suficiente numa análise; é preciso perceber quais relações há entre elas e avaliar a trama por elas constituída, isto é, a rede relacional, o percurso figurativo. $\mathrm{Na}$ análise de um texto, é preciso apreender o encadeamento das figuras e temas (percursos figurativos e temáticos), que é o ponto privilegiado de manifestação ideológica. A ideologia não se manifesta "nos níveis mais abstratos do percurso gerativo", "mas na concretização dos valores semânticos" (FIORIN, 200o, p. 75). Figuratização e narratividade são dois componentes inseparáveis de qualquer discurso.

A narratividade é a transformação de conteúdo e está presente em todos os textos (narrativos ou não); “é uma transformação situada entre dois estados sucessivos e diferentes. Isso significa que ocorre uma narrativa mínima, quando se tem um estado inicial, uma transformação e um estado final". Por sua vez, "Uma narrativa complexa estrutura-se numa sequência canônica, que compreende quatro fases: a manipulação, a competência, a performance e a sanção (FIORIN, 2000, p. 21; 22). As narrativas se manifestam, mormente, na forma linguística, no discurso.

Fiorin (200o, p. 3I) afirma que "Discurso é uma unidade de um plano de conteúdo, é o nível do percurso gerativo de sentido, em que as formas narrativas abstratas são revestidas por elementos concretos". Enunciado, por seu turno, consiste no ato de produção do discurso; marca o discurso em sua produção. A semiótica greimasiana evoluiu para a enunciação, paixões, expressão e continuidade, passou para um pós-estruturalismo.

No nível do discurso, as abstrações do nível narrativo se revestem de termos concretos. O plano de conteúdo se reveste do plano da expressão, que pode ser verbal ou não verbal. O percurso gerativo é um simulacro metodológico por simular a produção e a interpretação do significado, do conteúdo, levando-nos a ler um texto com mais eficácia. Portanto, o texto resulta da manifestação do discurso pelo plano da expressão (união: conteúdo mais expressão).

Os discursos são concretos e de identificação mais fácil; são ornados de aparências como racismo, tradicionalismo, religiosidade e outras. Numa análise, primeiro se vê o 
discurso, depois sua narrativa e, por fim, vem o nível mais profundo, onde estão as oposições semânticas, a base da construção do texto. Nesse sentido, os estudos semióticos de Greimas apresentam-se em formas de percursos; partem da aparência à imanência objetivando a verificação da produtividade de apreensão de processos de geração de sentido.

Greimas (1976) associou os dois arcabouços de suas teorias: a teoria linguística embasada, em parte, em Hjelmslev; a teoria filosófica, que busca na fenomenologia de Husserl o que nela há de Merleau-Ponty. Assim, a semiótica greimasiana concebe o texto como totalidade de significação, só recorre a elementos da ordem do histórico se estiverem semiotizados - uma característica que mantém compatibilidade com a abordagem bakhtiniana, que privilegia o contexto. O extradiscursivo é tratado ora como um texto associado às práticas humanas, ora o efeito do sentido gerado no texto. A estrutura do texto requisita e faculta como parte construtiva a presença do não textual.

Assim, sob o viés do percurso gerativo de sentido da semiótica e dos seus níveis (fundamental, narrativo e discursivo), em 4.4 Percurso Gerativo do Sentido do slogan em pauta, se procede à análise do slogan que é objeto de estudo desta pesquisa; antes, porém, é oportuno discorrer especificamente sobre slogan (enfatizando seu poder de influência) e sobre as características dos contextos político e econômico que envolvem o estudo de caso em questão.

\subsection{Slogan: poder de influência}

Slogans são textos de um discurso mais amplo. De origem escocesa, o termo slogan (=sluagh-ghairm) veio até o português pelo francês significando "grito de guerra de um clã” (REBOUL, I986, p. 78). Daí se deduz que etimologicamente o termo está relacionado ao campo semântico político, e não publicitário. É amplamente utilizado nos meios publicitários. Constitui-se de frase curta e simples, incisiva e atraente, em que se concentram características basilares do anunciante (empresa ou produto) objetivando manter-se na memória do consumidor. Sua elaboração não dispensa criatividade. O slogan

[...] possui a competência de representar e apresentar constantemente realidades culturais numa área específica da atuação humana, fomentando e solidificando, estratificando e 
estereotipando linguagens, contribuindo sobremaneira para o enriquecimento do repertório daqueles sistemas que lhes são afins (IASBECK, 2002, p. 53).

Se engenhosamente construídos, os slogans passam a ser a frase-chave, o logotipo verbal da empresa, do serviço ou produto; traduzem pela verbalização a inclinação ideológica, tal como o logotipo o faz pela forma visual. Mas eles também são utilizados em campanhas religiosas e políticas para propagar um lema ou concepções defendidas. $O$ slogan, segundo Perez (2004), "é o comando que desperta associações funcionais e emocionais. Quando bem construído e representativo, ele oraliza máximas que a coletividade vive piamente como verdadeiras, tornando-se parte do cotidiano".

Para que seja, portanto, apreendido de modo mais rápido, precisa primar pela brevidade, facilidade de comunicação e de fixação, precisa impactar e persuadir. É criado para ser repetido insistentemente e assim registrar na memória da recepção a ideia que se pretende passar. Como os destinatários do slogan são, em geral, heterogêneos e dispersos geograficamente, a estrutura desse texto deve ser elaborada de modo a desviar o pensamento reflexivo sobre o que nele se afirma. O que importa aí é a comunicação imediata, instantânea, automática, sem mais delongas para elucubrações sobre o significado. Muitas vezes,

O slogan funciona mais pelo seu significante do que pelo seu significado. Do ponto de vista das representações discursivas, o slogan assenta mais no seu carácter mobilizador e instrumental e menos na sua capacidade de esclarecimento, do ponto de vista informacional (ESPÍRITO SANTO, 2006, p. 87).

O uso do slogan remonta a um passado longínquo. Quando Constantino assumiu o Império Romano (312-337d.C.) - Roma, em franca decadência e os cristãos se multiplicando e se reunindo com uma força descomunal, envolvendo, inclusive, grande número de soldados -, a saída encontrada pelo rei foi oficializar a nova doutrina no conhecido Concílio de Niceia. Constantino, na dependência do exército nas suas incursões pelo Oriente, declarou ter ouvido um chamado dos céus: In hoc signo vincis! (Sob este signo vencerei!). Nesses termos, então, declarou a solução vinda dos céus e, sem perda de tempo, determinou a confecção de estandartes contendo a cruz (representativa da morte de Cristo na cruz) seguida da referida frase (ou slogan). E funcionou porque o entusiasmo do 
exército foi o bastante para a conquista de Bizâncio, cidade dos turcos que passou a se chamar Constantinopla, em homenagem ao próprio rei (IASBECK, 2002, p. 57).

Apropriando-se desse expediente (ainda que não existisse o vocábulo slogan, mas já se tratava de um ícone associado a uma expressão verbal), o visionário Constantino desmontou ideologias adversas, enlevou a fidelidade dos povos a uma causa singular, sem questionamentos ou ponderações. É certo que anterior a Constantino, outras figuras de destaque na história já sabiam utilizar artifícios de tamanha eficácia "dos céus", sabiam lidar metaforicamente com fatos, situações reais. Basta que se leia a Sagrada Escritura - o que não é intento deste estudo, pois o que se quer é exemplificar o quão eficiente é um discurso breve, plástico e direto, mas imbuído de imagem e sincretismo linguístico, na promoção de mudanças comportamentais de massas populares (IASBECK, 2002, p. 58).

No séc. XX o slogan estabeleceu um diálogo entre essas duas esferas. Então o slogan passou a constituir-se como "instrumento requintado" de divulgação e propaganda ideológica, por grupos políticos e sistemas totalitários, visando, através do seu uso, a manipulação psicológica e ideológica das massas (ROMERO, 2008, p. 827).

"À entrada do terceiro milénio, o slogan mantém-se no seu formato original, curto e pragmático mas, simultaneamente, catalisador, emotivo e aglutinador de massas" (ESPÍRITO SANTO, 2006, p. 88). Mas ele tem vida curta: data de nascimento e morte. Está inscrito num determinado tempo. Detê-lo no tempo é esvaziá-lo simbolicamente em face de a dinâmica que o gerou não estar mais presente. $O$ panorama contextual é indispensável, pois o slogan "realça o signo de uma cultura, pontua os limites entre o desejável e o indesejável e orienta seu discurso para finalidades muito mais amplas" (IASBECK, 2002, p. 22).

Romero (2008, p. 828) afirma que "O tempo de um slogan é determinado pelas condições históricas de sua formação e por todo o contexto social, econômico e político". As regras do jogo de palavras são essenciais para a sua composição. Cada lance renova e revitaliza a linguagem sem que extrapole o contrato social para que seja suportado e assimilável pelo destinatário; "seu uso está sempre relacionado ao domínio das relações intertextuais e interdiscursivas que fazem com que o interlocutor recorra à memória discursiva" (TOMAZI; CARMELINO, 2010, p. II2). E assim o slogan é um dispositivo de grande poder de influência sobre seus destinatários. 
O slogan nasce banhado de cultura e ideologias que caracterizam certo posicionamento do anunciante. Tal posicionamento se infiltra no texto de modo que ele seja sempre lembrado quando expressado por alguém; seja, portanto, penetrante como um mantra da marca, que comunica de modo rápido o que a marca é (o que a distingue das demais) e também o que ela não é (KOTLER; KELLER, 2012, p. 303). Há aí uma ação estratégica de projetar uma imagem envolta em valores no imaginário coletivo de certos segmentos da sociedade (o chamado público-alvo) para orientá-lo, pela sedução, a "comprar" a ideia divulgada, como sendo a diferente, a melhor entre as concorrentes.

Essa tarefa demanda o mapeamento dos concorrentes em seus pontos fortes e fracos para então sobrelevar a diferença do produto/ideia anunciado/a, pois "os pontos de diferença são os atributos ou benefícios que os consumidores associam fortemente a uma marca, avaliam positivamente e acreditam que não poderiam ser equiparados por uma marca da concorrência" (KOTLER; KELLER, 2012, p. 298). Eis aí o poder de influência do slogan. É por isso que

\footnotetext{
A comunicação de massa, tanto a comercial quanto a política ou cultural, dele fez uma arma cujo alcance ultrapassa de longe os limites de um grupo restrito, como os leitores de uma obra, os fregueses de uma loja a até os membros de uma multidão; uma arma destinada a sacudir este ser anônimo e sem rosto que é a multidão (REBOUL, i986, p. II).
}

Desse modo, o slogan traduz-se numa ferramenta fundamental, que usurpa espaços de certos grupos e, como uma epidemia, se prolifera, contagiando-os e carregando consigo o DNA da divulgação de determinada ideia, da propaganda. Nessa investida, o slogan, segundo Reboul (1986), desempenha três papéis: I) fazer aderir; 2) prender a atenção; 3) resumir. O destinatário inclui os elementos do grupo sejam eles simpáticos à ideia sejam eles opositores a ela. Assim, a função fática desnuda o que integra o cerne de toda ideologia: a conquista do poder pela fala. A ideologia é, portanto, um discurso que desaprova ou esmaga outro discurso; é um controle de palavra e de palavra confiscada (REBOUL, 1986, p. 12I). Assim, "Uma mensagem é ideológica quando dissimula as figuras que a tornam persuasiva e quando se atribui uma transparência que não tem, quando oferece seus clichês e seus hábitos como certezas" (REBOUL, 1986).

Mais específico do que o publicitário, o slogan político-ideológico está atrelado a condições histórico-contextuais de produção discursiva; sua duração é maior que a do publicitário. O slogan político, segundo definição de Reboul (1986), apresenta três características específicas: I) espontaneidade; 2) duração; 3) justificação de uma prática coletiva. Este último traço é representativo da vinculação slogan político/nacionalismo por buscar fundamentação de práticas políticas nacionalistas junto com conteúdos totalitários 
se apropriando, para tanto, de slogans nacionalistas capazes de desencadear no destinatário sentimentos patrióticos e nacionalistas - medida reveladora de íntima relação com a psicologia social.

Conforme Maigueneau (2000), a influência do slogan é intensificada pela mídia; como tal, consoante Espírito Santo (1997, p. II5),

[...] o slogan deve conter características que desencadeiem a sua rápida memorização, do ponto de vista auditivo ou visual. O êxito do slogan passa por aspectos como a simplicidade, a graça, a graciosidade ou a fonética. Por outras palavras, "o slogan tem de conter um apelo suficientemente simples, facilmente compreendido e susceptível de ser uma senha de coesão do grupo. Este grupo, o dos apoiantes da força política, quer-se o mais alargado possível, tanto quanto possa permitir o acesso ao Poder".

Com efeito, em época de eleições surgem muitos slogans, mas nem todos funcionam em conformidade com a expectativa do anunciante. E é aí que está o ponto crucial na escolha certa do texto e da imagem, nas acertadas relações intertextuais e interdiscursivas que funcionam como estratégias de marketing que, além de persuadir o eleitor, constrói sobre o candidato um ethos envolto de razão, defensoria e afeto. Conforme Barthes (1964), imagem e texto se complementam, mas não em dosagem equilibrada. A primeira proporciona uma explosão de sentidos, incitando inumeráveis possibilidades de conotação; já o texto verbal é o ponto de ancoragem, o filtro que direciona a significação pretendida, é como se fosse a legenda da imagem. Assim, “A mensagem linguística afixada ancora o significado da mensagem icônica; dirige a leitura da mensagem icônica, pode interpretá-la" (Tradução nossa) (BARTHES, i964, p. 4I)².

No caso do slogan político, Maingueneau afirma ser preciso entender o seguinte:

I) subordina-se por natureza ao sistema de particitação, incluindo o(s) suporte(s) por onde é veiculado;

2) é repetido indefinidamente, implicando um ethos apropriado que caracteriza a pessoa;

3) há grupos (e não classes) militantes e transitórios (num determinado tempo) na particitação desses slogans que mantêm certa organicidade;

4) o hiperenunciador enuncia o slogan compatível com a manifestação e "varia em função da opção política dos agrupamentos” (MAINGUENEAU, 2005, p. 89).

\subsection{Brasil acima de tudo, Deus acima de todos: um estudo de caso}

\footnotetext{
2 "Le message linguistique fixe, ancre le sens du message iconique; il dirige la lecture du message iconique, il permet éventuellement d'interpréter l'image".
} 
A partir, principalmente, das manifestações de 2013 contra o poder no Brasil, decorrentes do sistema político brasileiro, verifica-se um processo de espetacularização assistido pelos mais diversos meios de comunicação. Em 2014, o resultado questionado da reeleição acirrada da presidente Dilma Housseff (a quarta consecutiva vencida pelo PT e a sexta consecutiva em que os dois principais candidatos eram do PT e PSDB).

O governo dilmista enfrentou graves crises políticas e econômicas, impelindo a presidente a medidas impopulares (aumento de impostos, cortes bilionários nos orçamentos). Em paralelo, seguiram exposições bombásticas da Operação Lava Jato trazendo à tona casos de corrupção insólitos, deixando a população brasileira indignada, um desvario que repercutiu uma imagem negativa do Brasil no mundo inteiro. Manifestações antigovernamentais se aproveitaram da impopularidade da presidente para exigirem a sua saída alegando violação de leis orçamentárias.

Nesse pacote, o impeachment da presidente dividiu o povo brasileiro: o "nós" e o “eles”. O vice Michel Temer assume a presidência; com uma base aliada no Congresso, aprovou certas medidas essenciais (Novo Regime Fiscal e Reforma Trabalhista, p. ex.) e, assim, de um lado, o país apresentava indicadores de melhoria no setor econômicos, no tocante à inflação e ao crescimento do produto interno bruto; de outro lado, aumentou o desemprego, gerando insatisfação popular. O quadro se torna mais malfadado com duas denúncias criminais do presidente em exercício pela Procuradoria-Geral da República. A rejeição dispara atingindo níveis na casa dos $80 \%$.

As eleições presidenciais passaram a ser o ponto nevrálgico mirado por ambos os lados ("nós" e "eles") para o estabelecimento legítimo de uma nova ordem. Treze (!) candidatos foram confirmados pelas convenções partidárias à Presidência da República. $\mathrm{O}$ líder disparado para vencer essas eleições, o ex-presidente Luiz Inácio Lula da Silva, é preso e condenado por corrupção, sendo impedido, portanto, de disputar o pleito e substituído por aquele que seria o seu vice, Fernando Haddad.

2018 foi um ano que, futuramente, será objeto de destacada atenção dos círculos historiográficos voltados ao estudo da história política e econômica brasileira, não somente pelo fato em si da eleição presidencial, que encerrou um ciclo de protagonismo polarizado entre PSDB e PT, elegendo o conservador candidato do PSL, Jair Bolsonaro, mas também por todo o contexto político, econômico e social que condicionou a disputa eleitoral, dominada pela radicalização política que tomou conta do debate, substituindo a proposição concreta de projetos para o país (FAP, 2018). 
Nas eleições do país, os candidatos sempre contaram com financiamento empresarial. Em 2018, foi vetado esse expediente e o período de campanha eleitoral foi reduzido. Em compensação, a internet ampliou seus espaços a partir da liberação do recolhimento por recursos de financiamento coletivo (as popularmente chamadas "vaquinhas"), o que, em contrapartida, gerou a difusão de uma gama de fake news na rede.

O mês de janeiro desponta com a incidência de casos de febre amarela, incluindo São Paulo como área de risco; Lula é condenado a 12 anos de prisão por corrupção passiva e lavagem de dinheiro. Em fevereiro, intervenção federal no estado do Rio de Janeiro. Em março, Temer é incluído na Operação Lava Jato e outros ministros mais chegados a ele são investigados (Eliseu Padilha e Moreira Franco); Marielle Franco (vereadora do PSOL, a mais votada da capital carioca) e seu motorista são assassinados a tiros - fato de proporções internacionais e ainda não esclarecido, pois

A resposta contundente que se esperava vir, diante da repercussão do caso, inclusive internacional, tem-se transformado numa frustração quase diária, em meio a indícios e especulações de que agentes públicos estiveram envolvidos com a trama e o seu trágico desfecho (O POVO, 2018).

Em abril, solicitação de habeas corpus para Lula pelos seus advogados é negada, sua prisão é decretada pelo então juiz Sérgio Moro. Em maio, greve nacional de caminhoneiros por cinco dias em protesto ao aumento do preço dos combustíveis, cobrança de pedágio por eixo suspenso e fim do PIS/Cofins sobre o diesel. "Segundo o Ministério da Fazenda, a greve custou $\mathrm{R} \$$ is bilhões, o equivalente a o,2\% do PIB” (EXAME, 2018), "paralisou serviços como fornecimento de combustíveis e distribuição de alimentos e insumos médicos" (JETSS, 2018); “desabamento de prédio de ocupação em São Paulo, deixou mortos, feridos e desabrigados" (JETSS, 2018). Em junho,

Os efeitos externos e internos também afetaram o principal índice do mercado de ações no Brasil, o Ibovespa. No dia 18 de junho, o Ibovespa fechou em baixa de $1,33 \%$ com 69.814 pontos, marca abaixo dos 70 mil pontos não registrada desde agosto de 2017. Esse foi o menor patamar registrado neste ano (EXAME, 2018).

Em julho, "a seleção brasileira se despediu do sonho do hexa e o Dr. Bumbum foi preso após a morte de uma paciente" (JETSS, 2018). Em agosto, indeferimento da candidatura de Lula pelo Supremo Tribunal Eleitoral. Em setembro, incêndio no Museu Nacional do Brasil (RJ); tentativa de assassinato do então presidenciável Jair Bolsonaro; 
lançamento da candidatura de Fernando Haddad (PT) e de sua vice Manoela D'Ávila (PCdo B). Em outubro, primeiro turno das eleições gerais (dia 7) e segundo (dia 28). Jair Messias Bolsonaro é o eleito.

A despeito de estar há mais de 20 anos na vida pública, Bolsonaro se lançou candidato à presidência do país embalado como um produto novo a colocar ordem no caos de um velho sistema político, desgastado pela corrupção. Sua patente de capitão funcionou como uma senha para a coesão do eleitorado e, consequentemente, para a sua vitória nas urnas.

Retórica política, imagem estrategicamente planejada e sagacidade fazem um militar retornar ao poder. O "mito" desponta

[...] como personagem antissistema nos protestos de 2015 e 2016, que culminariam no impeachment da ex-presidente Dilma Rousseff (PT). [...] Desde então, soube aproveitar um vácuo de poder causado pelo derretimento das principais lideranças do PT e PSDB - partidos que polarizaram as eleições presidenciais desde a redemocratização - em meio a escândalos. Ele consolidou o discurso contra malfeitos na administração pública e se vendeu como agente de mudança ao establishment político (UOL, 2018).

A indumentária de Bolsonaro é parte de sua retórica política. Quando fora esfaqueado, Bolsonaro trajava a camiseta amarela, a qual fora rasgada pelos médicos que o assistiram para iniciar os procedimentos emergenciais cirúrgicos. Enquanto estava hospitalizado, um de seus apoiadores, o filho Flávio Bolsonaro, lançou um vídeo em que aparece a camiseta amarela manchada de sangue em torno de um rasgo (Cf. Figura 2). Trata-se, pois, de uma montagem, porque os escritos que vemos em verde sobre o amarelo da camisa (cores da Bandeira do Brasil) foram colocados por computador. Ainda assim, a camiseta "foi adotada como mantra por seus seguidores pelo país" (UOL, 2018).

Figura 2: Camiseta amarela manchada de sangue e editada 


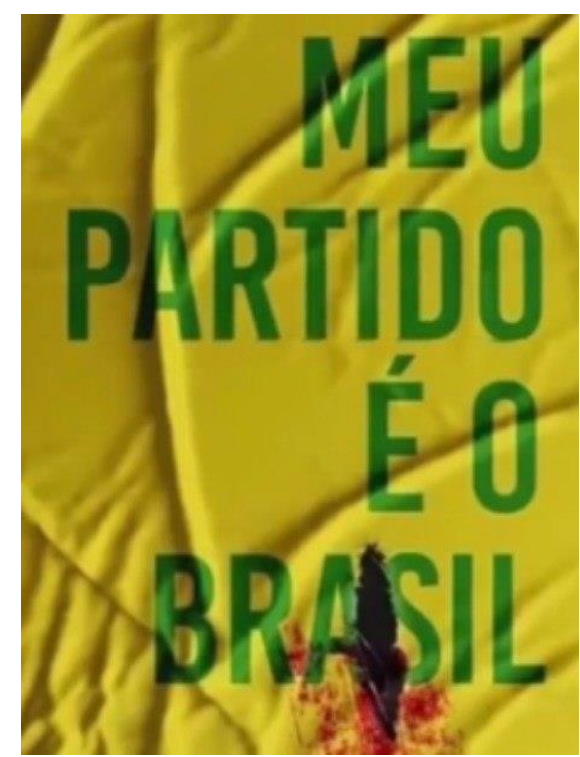

Fonte: Último Segundo, 9 set. 2018. Disponível em: 〈https://bit.ly/2wYfsUS〉. Acesso em: 27 dez. 2018.

Por certo, Bolsonaro não encomendaria um atentado contra ele próprio apenas para comover o eleitor e assim ganhar o seu voto. Mas, a facada que levou teve esse resultado, preservando-o do enfrentamento com outros candidatos nos debates políticos transmitidos ao vivo em rede nacional de televisão. E no recluso de sua residência comandou sua campanha a seu bel prazer. Para o cientista político da PUC-MG, Marco Camargos, “A gravidade da lesão, seu relato, as minúcias de seu quadro de saúde explicadas, tudo isso foi humanizando o candidato para as pessoas" (UOL, 2018). A vulnerabilidade do "mito" esfaqueado, costurado em grande parte do corpo, se transformou em potência, valorizou sua imagem e comoveu o eleitorado.

Outro expediente de imagem aliado ao slogan foi o gesto de arma com as mãos um dos motes da campanha de Bolsonaro. O candidato chegou a ensinar crianças (como a um garoto em Araçatuba-SP), a simular um revólver com os dedos. "Você sabe atirar? Você sabe dar tiro? Atira. Policial tem que atirar”, afirmou Bolsonaro à criança, que estava em seu colo com um uniforme da Polícia Militar (UOL, 2018).

\subsection{Percurso Gerativo do Sentido do slogan em pauta}

A análise semiótica de um discurso conta com crenças, atitudes e sentimentos da sociedade manifestados em suas linguagens; portanto, a análise do corpus deste trabalho 
envolve uma gama de situações, num percurso que gera o sentido. Desse modo, observamse, no slogan e nas imagens em estudo, discursos latentes a textos políticos e seus peculiares valores socioculturais. Evidencia-se uma preocupação em se pautar o tempo todo por uma categoria semântica que se fundamenta em oposições, as quais são o foco do ataque na arena verbal constituída pelo discurso. Em um plano, estão a bandeira nacional, o verde amarelo, Brasil acima de tudo, Deus acima de todos. A locução adverbial acima de parece puxar o brasileiro do fundo do poço, tangenciá-lo. No plano do conteúdo, há um sentido nele inscrito capaz de ressoar como uma âncora da salvação. No plano da manifestação, há uma sequência linear canônica. Deduz-se que do lado oposto da configuração discursiva esteja o inimigo do País figuratizado nas bandeiras vermelhas, na cor vermelha, na corrupção deflagrada, na derrocada do país, no esquecimento de Deus. "Mesmo quando os elementos da enunciação não aparecem no enunciado, a enunciação existe", "há uma instância pressuposta da enunciação" (FIORIN, 2000, p. 39).

Desse modo, o PGS vai sendo construído sugerindo um país melhor, governado por uma figura construída para ser identificada como mito. "O mito constrói-se com a junção de termos opostos" (FIORIN, 200o, p. 19). Euforia/disforia "não são valores determinados pelo sistema axiológico do leitor, mas estão inscritos no texto" (FIORIN, 200o, p. 20). No discurso de Bolsonaro é considerado algo positivo, eufórico, exemplos como: criminalizar o aborto, armar o cidadão de bem, diminuir a maioridade penal e a própria figura do capitão reformado, defensor de medidas de linha dura na contenção da violência. No nível da manifestação, considerando-se aí o efeito da oralidade, a fala firme do candidato entra em sintonia com os anseios do povo brasileiro, cansado de viver em um país cujas esperanças estavam/estão por um fio. Nesse cenário, o enunciador Bolsonaro lança mão de uma proposta de governo que vai de encontro ao fatalismo petista de então; mobiliza o aparelho enunciativo pelos recursos euforia/disforia procurando manter uma coerência interna, bem convincente: num plano, o status quo, que precisa ser combatido; noutro, a nova proposta. É o que se observa no quadro abaixo.

\section{Quadro 2 - Percurso Gerativo do Sentido}

\begin{tabular}{|l|l|}
\hline Percurso do fatalismo petista & Percurso da proposta bolsonarista \\
\hline Formação de quadrilha & Corrupção: tolerância zero \\
\hline
\end{tabular}




\begin{tabular}{|l|l|}
\hline Lulismo & Antipetismo \\
\hline $\begin{array}{l}\text { Proposta de educação pautada em gênero, desde as } \\
\text { primeiras séries. }\end{array}$ & $\begin{array}{l}\text { Proposta de educação sem partido. Retorno ao } \\
\text { respeito. Gênero deve ser ensinado na família. } \\
\text { Ealores familiares conservadores. } \\
\text { Material didático: kit gay. }\end{array}$ \\
\hline $\begin{array}{l}\text { Casais homoafetivos. } \\
\text { Subversão a valores conservadores. } \\
\text { Sim ao aborto. }\end{array}$ & $\begin{array}{l}\text { Defesa pela família tradicional, heterossexual. } \\
\text { Resgate de valores morais. Não ao aborto. }\end{array}$ \\
\hline Estatização & Privatização \\
\hline Cabide de empregos & Enxugamento da máquina pública \\
\hline $\begin{array}{l}\text { Segurança: ação policial controlada; } \\
\text { desarmamento da população. }\end{array}$ & $\begin{array}{l}\text { Segurança: liberdade de ação policial sem punição; } \\
\text { armamento do cidadão de bem. }\end{array}$ \\
\hline
\end{tabular}

Fonte: Elaboração própria.

O slogan utilizado por Bolsonaro ("O Brasil acima de tudo. Deus acima de todos") se traduz em valores - segurança, família, tradição - perseguidos, sonhados ou idealizados pelos brasileiros durante as últimas décadas. No empenho para regatar valores conservadores, o enunciador buscou seu lema na Brigada Paraquedista do Exército; recorreu muitas vezes à religiosidade, citando inclusive vez ou outra o versículo bíblico "E conhecereis a verdade, e a verdade vos libertará" (JOÃO 8:32. BÍBLIA SAGRADA, 1980). E assim,

As teorias da Semiótica vieram-nos proporcionar o Instrumental que julgamos adequado para penetrar, sem preconceitos, alguns segredos capazes de tornar os slogans - essas frases breves e compactas - tão pregnantes, tão sedutoras, enfim, tão significativas a ponto de perturbarem produtivamente as diferentes percepções da realidade (IASBECK, I995, p. 22).

O slogan bolsonarista migrou da mídia impressa para as telas mais contemporâneas dos smartphones, atingindo as classes sociais de $\mathrm{A}$ à $\mathrm{D}$, graças aos elementos semióticos estruturais tão atraentes e adequados para o momento vivenciado pela nação brasileira. $\mathrm{O}$ slogan impregnou a cultura do povo, que passou a repeti-lo em sua consciência, como ocorrera na Alemanha nazista quando Hitler repetia: Sieg Heil! Heil Hitler! Heil mein Führer! (=Salve, meu líder!). Em 2018, travestida de ideias afins, o Capitão brasileiro o imita com eficácia suficiente para sedimentar relações funcionais no modo de pensar do povo brasileiro.

A configuração discursiva pode despertar a paixão. Conforme Fiorin (1999), a semiótica reconhece a paixão em todos os textos como um componente dos estados de alma, perturbador. Para o autor, as paixões movem as ações humanas fazendo emergir um sujeito em ação. Mesmo identificando paixões com estados de alma, elas não se restringem 
ao sujeito, o qual, na acepção da semiótica, não é real, é produto do discurso, é imagem do sujeito da enunciação. Sendo assim, o processo da enunciação deve ser levado em consideração ao analisar, no slogan, as paixões que o motivam.

A semiótica impele o pesquisador a buscar em outros domínios do saber elementos de composição da malha multidisciplinar indispensável ao entendimento do sentido do discurso, daí a busca de identificação do slogan no seu trajeto histórico e o seu signo emblemático a serviço do "mito" Bolsonaro. Um slogan fez o marketing do candidato, mas que requereu a priori, em seu percurso gerativo, conhecer o eleitor brasileiro, sua cultura e necessidades essenciais do momento, não apenas para provê-las, mas sobretudo para provocar outras expectativas a serem satisfeitas com a sua vitória eleitoral. A imagem da Bandeira do Brasil, as cores verde e amarela, enfim texto e imagem (relações semióticas) utilizados adequadamente se tornaram, com efeito, um mecanismo retórico-persuasivo econômico nas palavras, um todo harmônico deveras eficaz para tocar a essência do imaginário do eleitor.

Assim, o slogan cumpre sua missão peculiar e preestabelecida: concretizar a intencionalidade do locutor com suas características retóricas indo do pragmático, da prática, da função ao poético, à palavra, ao mito. As imagens agregadas foram uma de suas funções. Mas o produto anunciado precisa parecer belo, atraente, desejável. A mensagem veiculada atuou como um ruído cativante; semantizou o objeto/candidato de modo que, prenhe de sentidos, tocasse nos valores da sociedade, manipulando-os e movendo-a com habilidade.

Brasil (figuratizado no candidato Bolsonaro - manipulador) acima de tudo (povo manipulado); Deus (manipulador) acima de todos (povo - manipulado). Nesse caso, há a manifestação de um juízo positivo - uma sedução - do manipulador sobre a competência do manipulado. " $\mathrm{Na}$ fase da competência, o sujeito que vai realizar a transformação central [o eleitor] da narrativa é dotado de um saber e/ou poder fazer. Cada um desses elementos pode aparecer no nível mais superficial do discurso sob as mais variadas formas" (FIORIN, 2000, p. 23).

Assim o slogan, repetido infinitamente, foi cumprindo sua função. No público receptor formou-se uma espécie de liberdade, ou de uma busca por ela, uma sensação de 
upgrade, de alforria, envolta de hedonismo. Foi preciso consumir o produto anunciado no slogan, ou melhor, consumir o discurso do produto - discurso entendido como processo semiótico, envolvendo o lugar do acontecimento da ação sígnica cujo resultado é a produção de sentido. Portanto, é um processo de produção determinado social e culturalmente. $O$ discurso se identificou com a ideologia, e não apenas com uma gramática; ele teve uma fisionomia.

“A performance é a fase em que se dá a transformação (mudança de um estado a outro) central da narrativa" (FIORIN, 2000, p. 23). O eleitor aderiu à candidatura de Bolsonaro, pois havia uma sanção, "o reconhecimento do sujeito que operou a transformação" (FIORIN, 200o, p. 23). Assim, o voto do eleitor elegeu Bolsonaro. A performance se realizou.

Nessa fase da sanção, presenciou-se o colapso de jogo de máscaras. Foram revelados segredos pessoais (divórcio, p. ex., do presidenciável), ações obscuras de familiares e vídeos antigos de expressões preconceituosas de Bolsonaro.

Entretanto, essas artimanhas da oposição não foram suficientes diante de um querer, poder e saber efetivar a performance da direita. E, por parte dos eleitores, veio a provocação de que cada voto não bolsonarista seria um voto na perpetuação do $\mathrm{PT}$ no poder e na certeza de que o Brasil seria uma Venezuela (intimidação). Nesse percurso, sustentaram a aura do slogan e outras frases de efeito proferidas ora pelo candidato (Meu partido é o Brasil, O Brasil precisa se libertar dos corruptos, Tolerância zero com o crime, com a corrupção e com os privilégios), ora por seus apoiadores (PT é o câncer, e Bolsonaro, a quimioterapia, Mi-to! Mi-to! Mi-to! Eu-vim-de-gra-ça! Eu-vim-de-gra-ça!).

No nível do discurso, as abstrações do nível narrativo se revestiram de termos concretos, pois a promessa de mais Brasil e menos Brasília reforçou, naquele momento, o cuidado para com os interesses do povo (educação, saúde de qualidade, segurança, castigo à corrupção, armamento do cidadão de bem e outros). Uma sequência de promessas constituiu-se em prerrogativa sine qua non para vencer as eleições, a sanção. Chegar ao poder supremo do País foi a competência indispensável para o cumprimento das promessas de campanha. Só assim, a narrativa pôde sair do projeto e se realizar. 
O presidenciável entrou em conjunção com o eleitor, o qual, com sua espada mágica de contos maravilhosos (seu voto) fez com que o príncipe conseguisse matar o dragão inimigo. Com essa "senha", Bolsonaro chegou ao "pote de ouro", ao poder (objeto concreto) para com ele obter outros objetos, realizar planos - fim último desse sujeito.

\section{CONSIDERAÇÕES FINAIS}

Deduziu-se deste estudo que a utilização da semiótica como método de análise demanda, como todo e qualquer método, procedimentos imprescindíveis: planejamento e definição de roteiro da investigação, tais como os delineados aqui; escolha das imagens analisadas; coleta de dados do anunciante e do público ao qual é dirigida a mensagem (hábitos, costumes e comportamentos) - para, enfim, detectar a intenção motivadora.

E foi assim que se verificou a força semiótica do slogan Brasil acima de tudo, Deus a acima de todos vinculado à campanha bolsonarista, sendo absorvido pelo pensamento do eleitorado brasileiro e promovendo uma coesão responsável pela vitória de Jair Messias Bolsonaro à Presidência da República deste País. Sim, enunciador com um discurso expresso no plano do conteúdo fundamentando relações existentes no mundo mediante textos, verbais e não verbais. Afinal, manifestações semióticas são formas por meio das quais o papel de atribuição da significação se dá pela expressão, como se deu com o slogan - um texto verbal que atuou como zona de ancoragem, como filtro a apontar para a significação almejada, como legenda da imagem.

Por certo, pelo enfoque metodológico do percurso gerativo de sentido, à luz da semiótica de Greimas, observou-se que o slogan sozinho não operou a transformação de um contexto nacional, foi todo um estado de coisas movido por paixão na mira de se atingir o estado de alma do eleitorado, atingindo os valores que estes sujeitos investem no objeto. Para tanto, intencionalmente o capitão imprimiu em seu discurso a virulência e a agressividade como meio de se fazer notado, ornou-se coerentemente com a sua fala, transcendeu o visual e o textual, evocou valores, sensações, narrativas que foram ao encontro das expectativas do eleitorado.

Por seu turno, o apelo contido no slogan - arrematando cada aparição pública do candidato, ao vivo e mais intensamente via midiática - foi suficiente o bastante no cumprimento de seu papel catalizador e instrumental, associado ao brado bélico do "mito", sempre apelando por meio das emoções, a ação pretendida pelo locutor. 


\section{REFERÊNCIAS}

BARTHES, Roland. Rhétorique de l'image. Communication, n. 4, 1964. Disponível em: $\langle$ https://bit.ly/2SQz2vo〉. Acesso em: 07 nov. 2018.

BÍBLIA. Português. Bíblia sagrada. (Trad. Padre Antônio Pereira de Figueiredo). Edição Ecumênica. Rio de Janeiro: Encyclopaedia Britannica, I98o.

\section{ESPÍRITO SANTO, Paula do. Persuasão com Referências ao Actual Sistema Político} Português. Lisboa. ISCSP, 1997.

A mensagem política na campanha das eleições presidenciais: análise de conteúdo dos slogans entre I976 e 2006, p. 83-102. Comunicação \& Cultura, n. 2, 2006.

EXAME. Retrospectiva 2018: veja fatos que marcaram a economia, 27 dez. 2018. Disponível em: 〈https://abr.ai/2GFuC8r >. Acesso em: 27 dez. 2018.

FAP. Fundação Astrojildo Pereira. A direção. Retrospectiva 2018. Disponível em: <https://bit.ly/2GQXXgC〉. Acesso em: 27 dez. 2018.

FIORIN, José Luiz. Sendas e veredas da semiótica narrativa e discursiva. Revista DELTA, v. 15, n. I, p.177-207, 1999.

Elementos da análise do discurso. 9. ed. São Paulo: Contexto, 2000.

As Astúcias da Enunciação: as categorias de pessoa, espaço e tempo. São Paulo: Ática, 2002.

GIL, Antonio Carlos. Como elaborar projetos de pesquisa. 4. ed. São Paulo: Atlas, 2002.

GREIMAS, Algirdas Julien. Sobre o sentido: ensaios semióticos. Trad. Ana Cristina Cruz Cezar et al. Petrópolis: Vozes, 1975.

Sémantique structurale. Paris: Larousse, 1976.

HJELMSLEV, Louis. A estratificação da linguagem. In: HJELMSLEV, Louis. Ensaios linguísticos. São Paulo: Perspectiva, I99I.

Prolegômenos a uma teoria da linguagem. São Paulo: Perspectiva, 2006.

IASBECK, Luiz Carlos Assis. A palavra dos bancos: um estudo semiótico dos slogans publicitários das instituições financeiras. Revista Brasileira do Comércio (Intercon), São Paulo, v. XVIII, n. I, p. 21-36, jan./jul., I995. 
. A arte dos slogans: as técnicas de construção das frases de efeito no texto publicitário. Brasília-DF: Upis, 2002.

JETSS. O bom da notícia. Retrospectiva, 2018. Disponível em: $\langle$ https://bit.ly/2ESIdrh $\rangle$. Acesso em: 27 dez. 2018.

KOTLER, Philip; KELLER, Kevin Lane. Administração de marketing. (Trad. Sônia Midori Yamamoto; revisão técnica Edson Crescitelli). I4. ed. São Paulo: Pearson Education do Brasil, 2012.

LARA, Glaucia Muniz Proença; MATTE, Ana Cristina Fricke. Ensaios de Semiótica: aprendendo com o texto. Rio de Janeiro: Nova Fronteira, 2009.

MAINGUENEAU, Dominique. A noção de hiperenunciador. Polifonia, v. ıo, n. ıo, Cuiabá-MT. 2005.

O POVO. Editorial. As respostas à morte de Marielle Franco. i6 dez. 2018. Disponível em: 〈https://bit.ly/2BHD8OK〉. Acesso em: 27 dez. 2018.

REBOUL, Olivier. O slogan. Cultrix. São Paulo.ı886.

ROMERO, Jorge Henrique da Silva. Slogan e ideologia: o slogan político como instrumento de projetos nacionalistas. $\mathbf{I}^{\mathbf{a}}$ Jornada Internacional de Estudos do Discurso (JIED) 27, 28 e 29 de março de 2008. Disponível em: 〈https://bit.ly/2Solsız〉. Acesso em: 23 maio 2018.

SAUSSURE, Ferdinand. Curso de linguística geral. (Trad. Antônio Chelini, José Paulo Paes e Izidoro Blikstein. 26. ed. São Paulo: Cultrix, 2006.

SEMIOSIS. Disponível em: 〈https://bit.ly/2DWkmG7〉. Acesso em: o2 dez. 2018.

TOMAZI, Micheline Mattedi; CARMELINO, Ana Cristina. Slogan político: ethos e polifonia em questão, 20p. 2010. Disponível em: 〈https://bit.ly/2HOsYIL〉. Acesso em: 23 maio 2019.

ÚlTiMO SEGUNDO. Política. Campanha de Bolsonaro usa montagem de camiseta com sangue, 9 set. 2018. Disponível em: 〈https://bit.ly/2wYfsUS $\rangle$. Acesso em: 27 dez. 2018.

UOL. Eleições 2018. Um capitão no Planalto. Disponível em: $\langle$ https://bit.ly/2RcR $9 \mathrm{Oj}>$. Acesso em: 27 dez. 2018.

YIN, Robert. Estudo de caso: planejamento e métodos. Porto Alegre: Bookman, 2015. 